\title{
Using Double-Bounded Dichotomous-Choice to Estimate Households' Willingness to Pay for Improved Water Quality in Bac Ninh Province of Vietnam
}

\author{
Nguyen Van Song1*, Vu Ngoc Huyen#, Le Thi Phuong Dung1\#, Nguyen Thi Thuy ${ }^{3}$ \\ ${ }^{1}$ Faculty of Economics and Rural Development (FERD), Vietnam National University of Agriculture (VNUA), Trauquy, Gialam, \\ Hanoi, Vietnam \\ ${ }^{2}$ Faculty of Accounting and Business Management (FABM), Vietnam National University of Agriculture (VNUA), Trauquy, \\ Gialam, Hanoi, Vietnam \\ ${ }^{3}$ Vietnam National University of Agriculture Press (VNUA-Press), Vietnam National University of Agriculture (VNUA), \\ Trauquy, Gialam, Hanoi, Vietnam \\ Email: nguyensonghua@gmail.com
}

How to cite this paper: Song, N.V., Huyen, V.N., Dung, L.T.P. and Thuy, N.T. (2019) Using Double-Bounded Dichotomous-Choice to Estimate Households' Willingness to Pay for Improved Water Quality in Bac Ninh Province of Vietnam. Journal of Environmental Protection, 10, 1407-1418. https://doi.org/10.4236/jep.2019.1011083

Received: October 2, 2019

Accepted: October 29, 2019

Published: November 1, 2019

Copyright $\odot 2019$ by author(s) and Scientific Research Publishing Inc. This work is licensed under the Creative Commons Attribution International License (CC BY 4.0).

http://creativecommons.org/licenses/by/4.0/ (c) (i) Open Access

\begin{abstract}
This study used double-bounded dichotomous-choice to estimate and analyze the factors affecting households' willingness to pay (WTP) for water quality improvement. This study notes that households with higher income, living near a polluted water source, using tap water instead of natural water, who are handicraft producers, and who have more members, are willing to pay more. However, households who rarely hear about environmental pollution issues and who are offered a higher bid are more likely to refuse to pay. Solutions to improve water quality are suggested such as to raise people's awareness through communication channels and social organizations; to increase income associated with environmental protection policies; to construct wastewater treatment plants; to encourage the relocation of production establishments to industrial parks and industrial complexes; to put regulations on collection, payment and sanctions in case of not declaring and paying fees into village conventions; to promulgate circulars, and bylaws to concretize and simplify regulations and policies of the Government and the Ministry of Natural Resources and Environment.
\end{abstract}

\section{Keywords}

Double-Bounded Dichotomous-Choice, Willingness to Pay, Water Quality Improvement, Handicraft Households 


\section{Introduction}

While the handicraft industry has contributed significantly to the local economy, the results of surface water analysis, however, reveal that the concentrations of pollutants exceeded the Vietnam Permissible Standards (VPS) several times. At the agricultural processing villages, the $\mathrm{BOD}_{5}$ levels exceeded 5.8 - 56.3 times the VPS; the COD levels exceeded 28.2 times the VPS; while the TSS, ammonia, and coliform levels exceeded VPS more than 10 times. In comparison with the figures for 2016, the pollutants' contents in wastewater in 2018 increased $3-4$ times. It is of note that the coliform in the wastewater sample collected in 2018 was 300 times as high as that in 2016 [1]. This shows that water pollution in Bac Ninh's handicraft villages is becoming more and more severe.

There are many pollution control policies that were issued by Bac Ninh People Committee. However, these regulations have never been implemented in handicraft villages. While Bac Ninh province had some wastewater treatment plants, the wastewater treatment system in Khac Niem, for instance, was used for one year only because the system did not meet the required volume of wastewater from vermicelli making. Moreover, the wastewater treatment system in Dai Bai operated only in 2 years due to a lack of funds.

Bac Ninh government's solution focuses on building wastewater treatment plants. A study of people's willingness to pay to improve water quality is important. This can help in assessing financial issues as well as people's welfare from water quality improvement program. Hence, this study aimed to analyze people's opinion on water pollution and water quality improvement, estimate people's willingness to pay, and identify the factors of the affect willingness to pay for water quality improvement.

\section{Review of Literature}

Research results of Akhtar et al. [2] have found the relationship of WTP with socio-economic factors, showing that income is the most significant impact on WTP to improve water supply. Hundie and Tariku [3] estimated the people's willingness to pay (WTP) for better water service quality in Jigjiga City. The results show that household income, family size, water source, and age of the respondents significantly affect WTP in order to improve water service provision. Using the censorship econometric model (Tobit), the study results showed that the average WTP surcharge for better drinking water quality was $\$ 3.1$, accounting for about $0.22 \%$ of the average income of family in Mexico City. The ratio of WTP to the income of the poor is larger, reflecting the importance of improving water quality for the poor [4]. Saz-Salazar et al. [5] used CVM to estimate consumers' willingness to pay (WTP) to improve urban water supply infrastructure and reduce leakage. Research results show that, on average, people are willing to pay more for their water bill, from $€ 8.23$ to $€ 9.65$. Wang et al. [6] applied the CVM method to estimate the willingness of households to pay for water quality improvement, the results show that, on average, one Dali household is available. 
willing to pay about 27 yuan per month, accounting for about $1.7 \%$ of household income. People are willing to pay an average of N972 (US\$2.7) per month for improved water services. Regression analysis results (e.g. Akeju et al. [7]) show that age, income, access to water, education, water quality, frequency of water supply and gender are the influencing factors. to people's willingness to pay (WTP) for improved water services in the study area. The lower limit of the average WTP for installing a new advanced water treatment system is about US $\$ 2$ per month for each household in Korea. Gshwandtner et al. [8] used the double limit binary option method to evaluate the determinants of WTP and water consumption. Results from the study indicate that approximately $67 \%$ of households in the study area are willing to pay the initial bid provided to improve their water service. About $93 \%$ of households are willing to pay some money for improving water services. The estimated average WTP for 20 liters of water is E0.471. Household income, education, gender, distance and owning a backyard garden significantly affect WTP [9]. Beaumais et al. [10] estimate willingness to pay (WTP) for better tap water quality from 10 OECD countries. Results showed that households were willing to pay $7.5 \%$ of the average annual water bill to improve tap water quality. WTP is positively associated with income, education, environmental concerns, health concerns, and taste with tap water.

The study of Markov et al. [11] selected Sequencing batch reactor (SBR) to treat polluted water as most appropriate process having the lowest investment, operation and maintenance cost, as well as the highest score on the non-monetary multi criteria analysis.

Some methods try to "price" non-market goods by examining the relationship of "price" with market rules. Brox et al. [12] estimated the WTP for improved water quality in residential areas in the Grand River basin in the Province of Ontario, Canada, Trang et al. [13] applied Experiment (CE) technique in Choice Modelling (CM) approach for the study. The results showed that total annual environmental fee for wastewater treatment.

Double-bounded dichotomous choice (DBDC) is one of the elicitation procedures. With DBDC, the respondent says "yes" or "no" to a stated sum and is then asked to say "yes" or "no" to higher/lower bids. This technique is more efficient than single-bounded dichotomous choice (SBDC) as more information is elicited about the respondent's WTP. However, all the limitations of the SBDC still apply, such as: 1) the values obtained from dichotomous choice elicitation are significantly larger than those resulting from comparable open-ended question; 2) some degree of yes-saying is also possible, and 3) the starting point is biased [14]. Trang et al. [15] pointed out the major factors affecting their willingness to pay for the establishments of a wastewater treatment plant are their level of education, quantity of households' untreated wastewater.

By employing DBDC, Jinsoo and Jihyo [16], Abdullah and Jeanty [17], and Nasreen et al. [18] confirm the conclusions by Haab and McConnell [19] that 
there are three ways why which DBDC is more efficient than the single-bounded format. First, the "yes-no" and "no-yes" provide a clear bound of WTP; second, the "no-no" and "yes-yes" estimate efficiency gains; and third, the number of responses is substantially increased, especially for larger sample sizes. Some economists suppose that indignation and guilt are two sides of the same effect of applying DBDC. Indignation will occur when respondents perceive that in answering initial dichotomous choice question (DC1), they have struck a deal with the interviewer. Thus, when asked about the higher amount in subsequent dichotomous choice question (DC2), the respondents feel that the interviewer has gone back on the deal. The guilt hypothesis occurs when respondents who state "no" to DC1 are asked a lower bid amount in DC2. This lower amount makes respondents feel a sense of social responsibility or guilt [20] [21].

\section{Methodologies}

\section{Survey Design and Data Collection}

With a total of 13,171 households engaged in handicraft production in Bac Ninh province, the sample size at $95 \%$ significance level should be 400 households. However, the sample size was increased to 700 households for a more reliable estimate. The sample size per village was based on the proportion of households engaged in handicraft production to total number of households in the five villages (Figure 1). Total simple sizes are 1000 households, 1000 households were divided into 5 study sites of Yen Phu, Khac Niem, Phong Khe, Dai Bai, and Da Hoi. These villages were five (5) out of the seven most seriously polluted water due to handicraft production in Bac Ninh province.

Analysis of Fundamental Factors Affecting the Level of People's Willingness to Pay

The acceptance probability $P$ is written as follows [22]:

$$
P=F(B)=1 /\left(1+\mathrm{e}^{-\Delta \eta}\right)
$$

where: $F(B)$ is the "survivor" function yielding the probability of accepting to pay at least $\$ B$.

$\Delta V$ is the change in utility caused by the considered improvement in safety if the person pays $\$ B$ for the improvement, that is,

$$
\Delta V=B_{0}+\beta_{1} \text { bid }+\beta_{2} \mathrm{Si}
$$

where: $S$ is a vector of socioeconomic factors such as age, sex, education, household size, and household income.

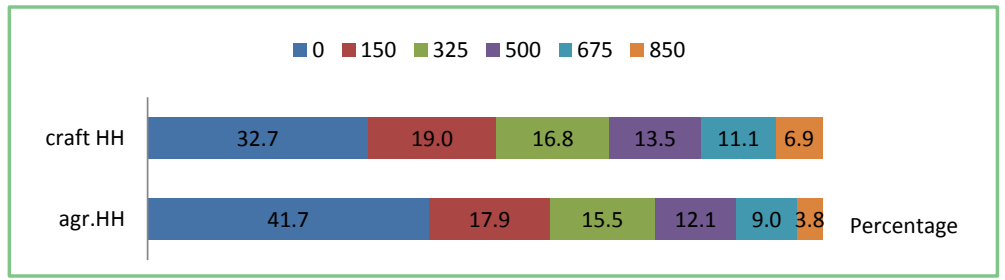

Figure 1. The willingness to pay (\%) by type of households, Bac Ninh province. 
$\mathcal{B}_{\mathrm{i}}(\mathrm{I}=0,1,2)$ are the estimated parameters.

The logistic function in Equation (1) can be written as:

$$
\operatorname{Ln}[P /(1-P)]=\beta_{0}+\beta_{1} \text { bid }+\beta_{2} \mathrm{Si}
$$

The estimation of the coefficients using binary logistic model includes two related models which were expressed as:

$$
\begin{aligned}
& Y_{1}=\beta_{01}+\beta_{11} \mathrm{bid}_{1}+\beta_{21} \mathrm{Si} \\
& Y_{2}=\beta_{02}+\beta_{12} \mathrm{bid}_{2}+\beta_{22} \mathrm{Si}
\end{aligned}
$$

where $Y_{1}, Y_{2}$ are the binary responses to the WTP questions; bid $\mathrm{b}_{1}$ and $\mathrm{bid}_{2}$ are the bids in the first and second bid questions; $\mathrm{Si}$ represents the socio-demographic variables; $\beta_{01}, \mathcal{B}_{11}, \mathcal{B}_{21}, \beta_{02}, \beta_{12}$, and $\mathcal{B}_{22}$ are the estimated coefficients. $Y, Y_{1}, Y_{2}$ are the binary responses ( $Y=1$ if they agree to pay, $Y=0$ if they do not agree to pay).

\section{Parametric Approach to Estimate Willingness to Pay}

The Mean WTP is estimated by using binary logistic model as follows:

From the model $Y=\beta_{0}+\mathcal{B}_{1}$ bid $+\mathcal{B}_{\mathrm{i}} X_{i}$, we have:

Mean WTP $=\frac{\beta_{0}+\beta_{i} \bar{X}_{i}}{\beta_{1}}$

In which $\bar{X}_{i}$ is mean of $X_{i}$.

Estimating the Total Funding for Rehabilitation of Water Sources from People

The following formulas were used:

Real funding

$=$ Average WTP $\times$ Percentage of Households $(\mathrm{HHs})$ willing to pay $\times$ Total HHs

Potential funding $=$ Average $\mathrm{WTP} \times$ Total $\mathrm{HHs}$

\section{Results and Discussions}

\section{People's Willingness to Pay for Improved Water Quality}

Based on DC1 model, $64.7 \%$ of the respondents are willing to pay to improve water quality (Table 1). Moreover, the percentage of "Yes"- "No" responses indicates that the acceptance rate falls when the suggested bid gets higher.

As shown in Figure 1, the proportion of agricultural households refusing to pay was $10 \%$ higher than handicraft households. When the given bids are increased, the percentage of handicraft households willing to pay was higher than agricultural households. Most of handicraft households think that they take more legal responsibility of water pollution and therefore have to pay for the water improvement program.

Depending on the first reply, i.e., "yes" or "no", the respondents were asked for their WTP for a second follow - up bid to which they answered either "yes" or "no". If the respondents answered "no" ("yes") to the first bid, the follow up bid is a lower (higher) amount. The results are presented in Table 2.

About $82.38 \%$ of the respondents agree to pay the two given bids (150 - 225). The percentage of people saying "yes - yes" fell when the given bid was raised. 
About $37.31 \%$ of the respondents disagreed to pay the highest group amount of 850 - 425. This rate tends to decrease when the suggested bid decreases. At the lowest group bid (150 - 75), the percentage of "no - no" responses was only $6.19 \%$. The results from DC2 model and DC1 model again confirm that the "yes" response monotonically decreases (increases) as the offer amount increases (decreases), indicating that a higher bid would result in a lower probability of saying "yes" to the WTP question.

The funding that will be obtained from people to improve the environmental quality of water was estimated according to the household types. These funds can be obtained through a socialization program on improved environment Table 3.

Table 1. The probability of "Yes - No" responses of households for the first bid under the DC1 model.

\begin{tabular}{ccccc}
\hline \multirow{2}{*}{ Bid } & \multicolumn{3}{c}{ “Yes” } & \multicolumn{2}{c}{ “No" } \\
\cline { 2 - 5 }$(1000$ VND) & No. & Percent $(\%)$ & 23 & Porcent $(\%)$ \\
\hline 150 & 187 & 89.05 & 60 & 10.95 \\
325 & 164 & 73.21 & 68 & 26.79 \\
500 & 131 & 65.83 & 69 & 34.17 \\
675 & 105 & 60.34 & 133 & 39.66 \\
850 & 60 & 31.09 & 353 & 69.91 \\
Total & 647 & 64.7 & 35.3 \\
\hline
\end{tabular}

Note: Total percent of "yes" was calculated by dividing the number of households agreed to pay by the total number of households surveyed.

Table 2. Responses of households to the two suggested bids (DC2 model).

\begin{tabular}{|c|c|c|c|c|c|c|}
\hline $1^{\text {st }} \mathrm{Bid}^{\mathrm{a}}$ & $\begin{array}{l}2^{\text {nd }} \mathrm{Bid}^{\mathrm{a}} \\
\text { (higher) }\end{array}$ & $\begin{array}{l}2^{\text {nd }} \mathrm{Bid}^{\mathrm{a}} \\
\text { (lower) }\end{array}$ & $\mathrm{Y} / \mathrm{Y}$ & $\mathrm{Y} / \mathrm{N}$ & $\mathrm{N} / \mathrm{Y}$ & $\mathrm{N} / \mathrm{N}$ \\
\hline 150 & 225 & 75 & $\begin{array}{c}173^{b} \\
(82.38)^{c}\end{array}$ & $\begin{array}{c}14 \\
(6.67)\end{array}$ & $\begin{array}{c}10 \\
(4.76)\end{array}$ & $\begin{array}{c}13 \\
(6.19)\end{array}$ \\
\hline 325 & 487 & 163 & $\begin{array}{c}124 \\
(55.36)\end{array}$ & $\begin{array}{c}40 \\
(17.86)\end{array}$ & $\begin{array}{c}35 \\
(15.63)\end{array}$ & $\begin{array}{c}25 \\
(11.16)\end{array}$ \\
\hline 500 & 750 & 250 & $\begin{array}{c}92 \\
(46.23)\end{array}$ & $\begin{array}{c}39 \\
(19.60)\end{array}$ & $\begin{array}{c}43 \\
(21.61)\end{array}$ & $\begin{array}{c}25 \\
(12.56)\end{array}$ \\
\hline 675 & 1012 & 338 & $\begin{array}{c}20 \\
(11.49)\end{array}$ & $\begin{array}{c}85 \\
(48.85)\end{array}$ & $\begin{array}{c}52 \\
(29.89)\end{array}$ & $\begin{array}{c}17 \\
(9.77)\end{array}$ \\
\hline 850 & 1275 & 425 & $\begin{array}{c}10 \\
(5.18)\end{array}$ & $\begin{array}{c}50 \\
(25.9)\end{array}$ & $\begin{array}{c}61 \\
(31.61)\end{array}$ & $\begin{array}{c}72 \\
(37.31)\end{array}$ \\
\hline
\end{tabular}

${ }^{\mathrm{a}}$ In $1000 \mathrm{VND}$; ${ }^{\mathrm{b}}$ Number of households; ${ }^{\mathrm{c}}$ Percentage of households.

Table 3. Estimation of total funding to improve water quality, Bac Ninh province.

\begin{tabular}{ccc}
\hline Item & DC1 & DC2 \\
\hline Mean WTP (VND) & 275,816 & 355,821 \\
Percentage of households who voted “yes” (\%) & 64.7 & 84.8 \\
Total number of households & 340,319 & 340,319 \\
Real number of households willing to pay & 220.186 & 288,590 \\
Potential funding (billion VND) & 93.86 & 121.09 \\
Real funding (billion VND) & 60.73 & 102.686 \\
\hline
\end{tabular}


The total potential funding that could be collected from households at Bac Ninh's handicraft in the DC1 model and DC2 model is 93.86 million VND/year (4.05 million USD/year) and 121.09 million VND/year (5.23 million USD/year), respectively. The total real funding calculated based on the number of people who are willing to pay at these villages in DC1 model and DC2 model is 60.73 million VND/year (2.62 million USD/year) and 102.686 million VND/year (4.43 million USD/year), respectively.

A notable and preeminent feature of this parametric method is that it allows to combine, analyze and integrate respondent's characteristics for the estimation of the average willingness to pay. This method also provides researchers with information on the validity and reliability of contingent valuation methods, and on the relevance and statistical significance for model testing and allows quantitative extrapolation based on statistical tests. In addition, the coherence and logic between the socio-economic characteristics of interviewees with the willingness to pay (resulting from this approach) are very valuable for policy makers in decision making related to socio-economic-environmental characteristics, customs and practices of the residential areas. This is especially meaningful for Kinh Bac, the cradle of Quan ho singing and for the custom of respecting relatives and family relations. This method helps to estimate the average WTP heavily based on the parametric model. In other words, if the parametric model is well handled, the estimated WTP will not be sensitive to the distribution selection of the survey samples. The estimates obtained largely depend on the assumptions of the model structure, as well as the preferences of the respondents. In the parametric model, in addition to endogenous variables, the socio-economic characteristics of the respondents, there must be appropriate exogenous variables, while in fact there exist only a few theories that provide guidance on appropriate exogenous variables.

Factors Affecting People's Willingness to Pay for Improved Water Quality

Binary logistic model was used to analyze the impact of factors on the household's "Yes" or "No" decision Table 4.

Running a binary logit regression, Table 5 shows the factors that affect decision to pay for water quality improvement in handicraft villages.

DC1 and DC2 models have quite similar conclusions on the factors affecting the people's willingness to pay for water quality improvement. Households with high incomes and using tap water are more likely to say "yes" to the given bid. This result is similar to the findings of [23] which revealed that the use of water from natural sources would induce higher probability to pay for improved water quality. Households using tap water are aware of hazards from using natural water source in the current polluted water condition so they tend to support water quality improvement programs. Households with higher income would have greater WTP for water quality improvement program. On the other hand, $\mathrm{HH}$ type in DC1 model is positive and significant. To reiterate, handicraft producers are aware of the negative impact of their production activities on water sources. So they are willing to pay for environmental and water quality improvement. 
$\mathrm{HH}$ size in DC2 has a positive and statistically significant coefficient, implying that households with more members would be more likely to say "yes" to the given bid.

Access to communication program ( $\mathrm{HH}$ apr), village and bid variables have negative and highly statistically significant coefficients. This means respondents who have heard about pollution problems tend to support water improvement programs. The negative coefficient of village, as found in the results from the study of Nasreen et al. [18], shows that households living in high risk zones tend to respond "yes". Households that are closer to the two contaminated Cau and Ngu Huyen Khe rivers would be more likely to support the projects to improve their water quality. As expected, the bids have a significant negative effect on the probability that a household is willing to pay either the first or the second bid amount, that is, the higher the bid, the lower the probability that a respondent agrees to pay). This conforms to the conclusions of Jin et al. [24] and Nasreen et al. [18].

Table 4. Describe the variables in the model.

\begin{tabular}{|c|c|c|}
\hline Variable & Describe & Note \\
\hline WTP & Willingness to pay of $\mathrm{HH}$ & $\begin{array}{l}\text { Yes }=1 \\
\text { No }=0\end{array}$ \\
\hline Age & Age of head of $\mathrm{HH}$ & Continuous variable \\
\hline Gender & Gender of head of $\mathrm{HH}$ & $\begin{array}{l}\text { Male }=1 \\
\text { Female }=0\end{array}$ \\
\hline Edu & Education level of head of $\mathrm{HH}$ & $\begin{array}{l}\text { Under high school }=1 \\
\text { High school }=2 \\
\text { Collge }=3 \\
\text { University/ above university }=4\end{array}$ \\
\hline $\mathrm{HH}$ size & Size of $\mathrm{HH}$ & Continuous variable \\
\hline HH type & Type of $\mathrm{HH}$ & $\begin{array}{l}\text { handicraft producers }=1 \\
\text { agricultural } \mathrm{HH}=0\end{array}$ \\
\hline HHapro & $\begin{array}{l}\text { Access to media on environmental } \\
\text { pollution }\end{array}$ & $\begin{array}{l}\text { Many times }=1 \\
\text { Sometimes }=2 \\
\text { never heard of it }=3\end{array}$ \\
\hline $\mathrm{HH}$ trade-off & $\begin{array}{l}\text { Trade-off between economic } \\
\text { development and the environment }\end{array}$ & $\begin{array}{l}\text { Agree }=1 \\
\text { Disagree }=0\end{array}$ \\
\hline Income & Income of $\mathrm{HH}$ & $\begin{array}{l}<10 \text { million VND/month }=1 \\
10-20 \text { million } \mathrm{VND} / \text { month }=2 \\
21-30 \text { million } \mathrm{VND} / \text { month }=3 \\
31-40 \text { million } \mathrm{VND} / \text { month }=4 \\
41-50 \text { million } \mathrm{VND} / \text { month }=5 \\
>51 \text { million } \mathrm{VND} / \text { month }=6\end{array}$ \\
\hline Village & Village & $\begin{array}{l}\text { KhacNiem (very far to polluted rivers ) }=1 \\
\text { Yen Phu (far to polluted rivers) }=2 \\
\text { Dai Bai (nomal to polluted rivers) }=3 \\
\text { Da Hoi (near to polluted rivers) }=4 \\
\text { PhongKhe (very near to polluted rivers) }=5\end{array}$ \\
\hline WaS & Water source $\mathrm{HH}$ using & $\begin{array}{l}\text { Use tap water }=1 \\
\text { Do not use tap water }=0\end{array}$ \\
\hline BID1 & The first bid & Continuous variable \\
\hline BID2 & The second bid & Continuous variable \\
\hline
\end{tabular}


Table 5. Factors affecting WTP, Bac Ninh province.

\begin{tabular}{|c|c|c|c|c|}
\hline \multirow{2}{*}{ Independent Variable } & \multicolumn{2}{|c|}{ DC1 } & \multicolumn{2}{|c|}{ DC2 } \\
\hline & Coefficient & Standard Error & Coefficient & Standard Error \\
\hline Age & -0.011 & 0.008 & -0.03 & 0.07 \\
\hline Edu & 0.37 & 0.108 & 0.118 & 0.102 \\
\hline Gender & 0.175 & 0.175 & 0.018 & 0.168 \\
\hline HHsize & 0.01 & 0.056 & $0.125^{* *}$ & 0.055 \\
\hline HH type & $0.518^{* * *}$ & 0.183 & 0.18 & 0.176 \\
\hline HHapr & $-0.403^{* * *}$ & 0.133 & $-0.362^{* *}$ & 0.128 \\
\hline HH trade-off & 0.189 & 0.190 & -0.289 & 0.181 \\
\hline Income & $0.581^{* * *}$ & 0.105 & $0.281^{* * *}$ & 0.083 \\
\hline WaS & $2.124^{* * *}$ & 0.360 & $1.036^{* *}$ & 0.343 \\
\hline Village & $-0.930^{* * *}$ & 0.124 & $-0.510^{* * *}$ & 0.116 \\
\hline BID1 & $-0.004^{* * *}$ & 0.000 & & \\
\hline BID2 & & & $-0.003^{* * *}$ & 0.000 \\
\hline \multicolumn{5}{|l|}{$\mathrm{BID} 2 \mathrm{mh}$} \\
\hline Constant & $3.912^{* * *}$ & 0.713 & $2.625^{* * *}$ & 0.660 \\
\hline $\mathrm{N}$ & \multicolumn{2}{|c|}{997} & \multicolumn{2}{|c|}{997} \\
\hline$-2 \log$ likehood & \multicolumn{2}{|c|}{1015.564} & \multicolumn{2}{|c|}{1102.650} \\
\hline Pseudo $\mathrm{R}^{2}$ & \multicolumn{2}{|c|}{0.336} & \multicolumn{2}{|c|}{0.241} \\
\hline LR chi2 & \multicolumn{2}{|c|}{279.180} & \multicolumn{2}{|c|}{192.094} \\
\hline Prob $>$ chi 2 & \multicolumn{2}{|c|}{0.000} & \multicolumn{2}{|c|}{0.000} \\
\hline
\end{tabular}

$* * *, * *,{ }^{*}$ significant at $1 \%, 5 \%$ and $10 \%$ probability levels, respectively.

\section{Conclusions}

The results of the study revealed that people in the study areas were aware of the worsening state of water pollution. Nearly all of the locals (96.8\%) agree that water pollution is the most serious problem and waste from handicraft production is the main reason. A vast majority (95.9\%) believed that environmental pollution has affected household health, production, consumption, and economic performance.

On average, according to DC1 model, about $64.7 \%$ of the households are willing to pay to improve the quality of the water environment. Double-bounded dichotomous-choice allows avoiding some bias of CVM. The WTP of households at Bac Ninh's handicraft villages in the DC1 and DC2 models was estimated to be $275,816 \mathrm{VND} /$ year and 355,821 VND/year, respectively. The total potential funding that could be collected from households at Bac Ninh's handicraft in the DC1 model and DC2 model is 93.86 million VND/year (4.05 million USD/year) and 121.09 million VND/year (5.23 million USD/year), respectively. The total real funding calculated based on the number of people who are willing to pay at these villages in DC1 model and DC2 model is 60.73 million VND/year (2.62 million USD/year) and 102.686 million VND/year (4.43 
million USD/year), respectively.

In studies of WTP, endogenous factors are often identified including socio-economic conditions of respondents. Besides endogenous variables, these studies require appropriate exogenous variables. In fact, very few theories provide guidance on exogenous variables. This study once again confirms the influence of socio-demographic characteristics of the respondents: Households who have high income, households who are production facilities, and respondents with larger family tend to agree with the given bid; households who get a higher bid are more likely to refuse the presented bid. In addition, the results of this study along with previous research help identify exogenous factors that can be included in the model to analyze the factors affecting WTP of people to improve water quality, such as: households living near contaminated water source, using tap water are willing to agree; households who have never heard about environmental pollution are not willing to pay the presented bid.

\section{Conflicts of Interest}

The authors declare no conflicts of interest regarding the publication of this paper.

\section{References}

[1] Center for Monitoring and Environment Quality (2018) Results of Water Analysis in Handicraft Villages of Bacninh Province. Bacninh.

[2] Akhtar, S., Dean, S., Anjum, F. and Javed, M. (2018) Determination of Willingness to Pay for Improved Water Supply in Selected Areas of Lahore. Chinese Journal of Urban and Environmental Studies, 6, 1-12.

[3] Hundie, S.K. and Tariku, L. (2016) Household's Willingness to Pay for Improved Water Supply: Application of the Contingent Valuation Method; Evidence from Jigjiga Town, Ethiopia. Romanian Journal of Economic Forecasting, 19, 191-214.

[4] Rodríguez-Tapia, L., Revollo-Fernández, D.A. and Morales-Novelo, J.A. (2017) Household's Perception of Water Quality and Willingness to Pay for Clean Water in Mexico City. Economies, 5, 12. https://doi.org/10.3390/economies5020012

[5] Saz-Salaza, S., Garcia-Rubio, M.A., Gonzalez-Gomez, F. and Picazo-Tadeo, A. (2016) Managing Water Resources under Conditions of Scarcity: On Consumers' Willingness to Pay for Improving Water Supply Infrastructure. Water Resources Management, 30, 1723-1738. https://doi.org/10.1007/s11269-016-1247-4

[6] Wang, H., Shi, Y., Kim, Y. and Kamata, T. (2015) Economic Value of Water Quality Improvement by One Grade Level in Erhai Lake: A Willingness-to-Pay Survey and a Benefit-Transfer Study. Frontiers of Economics in China, 10, 168-199.

[7] Akeju, T., Adeyinka, S., Olladehinde, G. and Fatusin, A. (2018) Regression Analysis of Residents' Perception on Willingness to Pay (WTP) for Improved Water Supply: A Case from Nigeria. Agricultural and Resource Economics. International Scientific E-Journal, 4. https://ideas.repec.org/a/ags/areint/274538.html

[8] Gshwandtner, A., Jang, C. and McManus, R. (2017) Improving Drinking Quality in South Korea: A Choice Experiment. Studies in Economics, 1720, School of Economics, Univ. Kent, Kent.

[9] Dlamini, N.M. (2015) Households' Water Use Demand and Willingness to Pay for 
Improved Water Services: A Case Study of Semi-Urban Areas in the Lubombo and Lowveld Regions of Swaziland. Research Theses 243464, Collaborative Masters Program in Agricultural and Applied Economics.

[10] Beaumais, O., Briand, A. and Katrin, M. (2014) What Are Households Willing to Pay for Better Tap Water Quality? A Cross-Country Valuation Study. Climate Change and Sustainable Development 165794, Fondazione Eni Enrico Mattei (FEEM).

[11] Markov, Z., Jovanoski, I. and Dimitrovski, D. (2017) Multi-Criteria Analysis Approach for Selection of the Most Appropriate Technology for Municipal Wastewater Treatment. Journal of Environmental Protection and Ecology, 18, 289-303.

[12] Brox, J.A., Kumer, R.C. and Stollery, K.R. (2013) Estimating Willingness to Pay for Improved Water Quality in the Presence of Item Nonresponse Bias. Water Policy, 5, 1651.

[13] Trang, T.T.T., Ranola, R.F. and Song, N.V. (2018) Households' Willingness-to-Pay for Wastewater Treatment in Traditional Agro-Food Processing Villages, Nhue-Day River Basin, Vietnam: Case Study in Hanoi City. Journal of Environmental Protection, 9, 1021-1033. https://doi.org/10.4236/jep.2018.910063

[14] Batman, I.J., Carson, R.T., Day, B., Hanemann, M., Hanley, N., Hett, T., Lee, M.J. and Lommes, G. (2002) Economic Valuation with Stated Preference Techniques. Edward Elgar Publishing, Cheltenham. https://doi.org/10.4337/9781781009727

[15] Trang, T.T.T., Ranola Jr., R.F. and Song, N.V. (2019) Factors Affecting the Households' Willingness-to-Pay for Wastewater Treatment in Agro-Food Processing Craft Villages, Nhue-Day River Basin, Vietnam. Journal of Environmental Protection, 10, 1119-1130. https://doi.org/10.4236/jep.2019.109066

[16] Jinsoo, K. and Jihyo, K. (2015) Korean Public's Perceptions on Supply Security of Fossil Fuels: A Contingent Valuation Analysis. Applied Energy, 137, 301-309. https://doi.org/10.1016/j.apenergy.2014.10.016

[17] Abdullah, S. and Jeanty, P.W. (2011) Willingness to Pay for Renewable Energy: Evidence from a Contingent Valuation Survey in Kenya. Renewable \& Sustainable Energy Reviews, 15, 2974-2983. https://doi.org/10.1016/j.rser.2011.03.016

[18] Nasreen, I.K., Brouwer, R. and Yang, H. (2014) Household's Willingness to Pay for Arsenic Safe Drinking Water in Bangladesh. Journal of Environmental Management, 143, 151-161. https://doi.org/10.1016/j.jenvman.2014.04.018

[19] Haab, T.C. and McConnell, K.E. (2002) Valuing Environmental and Natural Resources-The Econometrics of Non-Market Valuation. Edward Elgar Publishing, Cheltenham. https://doi.org/10.4337/9781843765431

[20] Bateman, I.J., Landford, I.H., Jones, A.P. and Kerr, G.N. (2001) Bound and Path Effect in Double and Triple Bounded Dichotomous Choice Contingent Valuation. Resource and Energy Economics, 23, 191-213. https://doi.org/10.1016/S0928-7655(00)00044-0

[21] Watson, W. and Ryan, M. (2004) Testing for Inconsistencies in Double Bounded Dichotomous Choice Contingent Valuation Studies. CES/ Health Economics Study Group, Paris, January 14-16 2004.

[22] Johannesson, M., Johansson, P.O. and O'Conor, R.M. (1996) The Value of Private Safety versus the Value of Public Safety. Journal of Risk and Uncertainty, 13, 263-275. https://doi.org/10.1007/BF00056156

[23] Khuc, Q.V. (2013) Household's Willingness to Pay Estimation for Safe Drinking 
Water: A Case Study in Vietnam. Master's Thesis, Corolado State Univ., Fort Collins, $71 \mathrm{p}$.

[24] Jin, J., Wang, W., Fan, Y. and Wang, X. (2016) Measuring the Willingness to Pay for Drinking Water Quality Improvements: Results of a Contingent Valuation Survey in Songzi, China. Journal of Water and Health, 14, 504-512. 